\title{
Mental Features of National Development in the Information Society
}

\author{
Svitlana Horova ${ }^{1}$ * [0000-0003-0151-0128], Valerii Horovyi 2 [0000-0002-2644-5249], \\ Olena Ufimtseva 2 [0000-0001-9118-0016] \\ ${ }^{1}$ National Library of Ukraine named after V. I. Vernadskyi, Kyiv, Ukraine \\ ${ }^{2}$ National Academy of the Security Service of Ukraine, Kyiv, Ukraine \\ *gorova.s@ukr.net
}

\begin{abstract}
The article considers the issues related to the restoration of the importance of mental factors as grounds for social development. In this case, the focus is on the restoration, because at the previous stage of social development these factors were largely overshadowed by industrial processes, which were the main grounds of social development for the formation of new nations. Restoration of mental traditions in modern social development became possible with the transition of society to the information stage of its development, to mass informatization, which created opportunities to involve almost all members of society, all its social structures in the cultural heritage of the past. Mental values are central to this heritage. The current demand for mental values is caused by the fact that in their main tendencies they reflect the ways to solve global problems of life on Earth, associated with the evolution of the human form of its reflection. Formed over millennia, the mentality retains its influence over a long historical period and determines the choice of certain values and orientations of the subject, which are manifested in mental immunity. It accumulates the most important features of social experience. The growing need for national development with the intensification of mental processes is becoming an important feature of modernity. Over the past decades, such opportunities have diminished significantly with the loss or unsystematic use of family ties between generations, the lack of access to historical traditions in most members of society, the national holiday and ritual sphere, with active migration processes. At the same time, nowadays modern informatization, information exchanges based on electronic information technologies enable representatives of all nations, people whose mental qualities are already deeply hidden in everyday life, to restore mental connections, mental features and continue to develop their spirituality. This process contributes to the growing opportunities for self-expression of each individual in modern social development, the enrichment of the creative potential of society.
\end{abstract}

Keywords: social consciousness, mentality, informatization, mental immunity, social development, ethnic groups and nations.

\section{INTRODUCTION}

In the conditions of information society development mental mechanisms acquire growing value in the activity of its members. This circumstance is due to the fact that a person at this stage of his or her development is faced with a growing array of diverse information. Immune mechanisms, based on centuries of historical experience, acquire the value of effective, defined by social practice, guidelines in the selection for activities of the information of the highest quality and own information creation. The orientation significance of the mentality in modern information activity acquires special importance in the conditions of the Russian-Ukrainian hybrid war.
Regarding this problem, the modern consideration of the mental immunity concept "as a resource of resistance to external negative influences on the mentality and the process of its development in condition of the surrounding reality influence" becomes important.

\section{RESEARCH METHODOLOGY}

To ensure reliable research results, the article uses such methods of scientific cognition as general scientific, interdisciplinary and disciplinary. The principles of historicism, objectivity, comprehensiveness, as well as such methods as abstraction, generalization and analogy, are used. 
The methods of empirical research are also used in the work. One of them is the method of observation, which is an active cognitive process that relies primarily on the work of human senses and substantive material activity, which, in this case, are reflected in the results of activities in the information space, in the Internet. Methods of classification, comparison and systematization of information, information-analytical method, methodical apparatus of social communications, methods of information and document analysis are also used.

\section{RESULTS OF THE RESEARCH}

The considered problems testify that while improving information technologies in modern social practice it is necessary to consider the growing activity of mental factors in the course of information exchange and new information creation. The positive components of the mental traditions of the Ukrainian people can be an effective force and an important guide to social progress.

\section{DISCUSSION OF RESULTS}

In the context of modern information issues, it seems appropriate to define the subject of consideration starting from the traditional formulations of this concept. From the standpoint of modern information processes, mentality can be considered as the formation and use of established stereotypes of worldview and behavior in the social sphere based on deep content assimilation of information about the world and society used by people.

In the industrial period of society development, the mental elements of human consciousness were overshadowed by industrial processes, the intensification of scientific and educational processes that served the process of society technologicalization. At the present stage of social development, informatization has contributed to both the rapid production of information and the individual ability of people to revive family contacts and mental ties. This mechanism is becoming increasingly important when navigating large arrays of information. At the same time, it is the mental component of the information basis of nations' life that is the most vulnerable to foreign information influences. This is due to the structural complexity of the mentality as a sociopsychological phenomenon and the inability to reproduce the lost content of its information and psychological resource when damaged or replaced by another resource. Due to these circumstances, the consideration of this problem is of particular importance today.

Features of national processes development in the information society have significant differences from their evolution in industrial society. Regarding the origins of the mentality, A. V. Furman notes that the ethnos is "genetically primary and structurally basic taxon (unit) of the socio-cultural life of people" [1, p. 12]. This fair remark of the researcher confirms the antiquity of the formation process of mental qualities of a human, its postponement to the period of tribal relations, based on which the mental qualities of the social person and the first formed social structures crystallized. Preservation of mental qualities to our time testifies:

- first of all, to their essential importance in the assertion of the right to identity and high viability, useful both for them and for general social development;

- secondly, to the penetration of these qualities into the deep layers of self-consciousness, formed since the existence of representatives of ancient ethnic groups, the formation of their collective memory.

At the beginning of the nations' formation, there was a process of uniting the common mental characteristics of ethnic groups close in worldview, the formation of common spiritual values, and their united spiritual culture. In the national dimension, ethnic consciousness is " ...the internal organization of the nation, the integrity of the nation, the people's awareness of their historical and genetic unity, of what defines a person as an individual and is formulated, above all, in the statements "I am French", "I am Ukrainian". The leading elements of the organization of the nation as a whole appeared in ancient times. The starting points are the forms of consciousness and mindset (mentality), which are developed by millennial experience and are more real and stable than any form of material existence and activity of the nation" $[2$, p. 111].

The growing manifestations of mental factors activity in the Russian-Ukrainian information confrontation in the process of informatization development convince in the stability and durability of this psychological mechanism. This is explained not only by the structural complexity of the mentality as a socio-psychological phenomenon but also by the awareness of the inability to reproduce the lost content of its information and psychological resource when damaged or replaced by another resource. Since "it is impossible to step twice into the same river", the conditions for this content creation cannot be repeated. It should also be noted that "it is unacceptable to reduce the mentality to a psychological phenomenon because then it turns out that the mentality is not a way of "rethinking", but a way of experiencing the world" [3, p. 124].

The sharpening of public attention to issues of mentality in recent decades has become a mass phenomenon, which is characteristic not only in regions of the world that do not differ in the level of cultural progress but also in highly developed countries within the so-called "golden billion". This is evidenced by various forms of self-awareness in many countries. This fact shows that modern civilization feels the need to mobilize little-needed at the industrial stage of development mental resources of their development. This is due to the growing importance of personal self-awareness in the 
information society. The development of global informatization has contributed to the activation of mental factors of individuality as effective reserves of national evolution in modern conditions.

The transition to the information stage of society and the development of mass informatization have created conditions for the growing motivation of the individual in access to the cultural heritage of the past and the mental values developed by all generations of each nation. And, thus, it revived for the representatives of each nation, regardless of whether they are within their national environment or outside it, the opportunity to join the mental values of their people, to enrich themselves with these values, to develop these values today.

From the standpoint of modern information processes, mentality can be considered as a result of the use and development of established stereotypes of worldview and behavior in the social sphere based on deep assimilation of the content of human community information about the world and society used by previous generations. These stereotypes as standards of assessment of environmental reality and behavior, which were established and enshrined in the experience of many generations of this ethnic group, distinguish one ethnic group from another, the culture of one community from the culture of another.

If to talk about the mental components of this process, it should be noted that at the previous stage of social development these components were largely overshadowed by industrial processes, which were the main factors of social development on which the formation of new nations was based. Theories of gradual adaptation of diasporic immigration associations in the "melting pot" of the environment of the leading Western countries were based on these ideas. This process at the appropriate stage of development was confirmed by the formation of the national unity of the North Americans and some other new national formations. In the process of social evolution, the idea of a "melting pot" was transformed into a formula of "unity in diversity", into the idea of multiculturalism. Modern Western states are trying to shape a society of general civic identity with the support of ethnocultural diversity through the influence of unifying factors: the establishment of religious identity, patriotism, high living standards, common spiritual values and interests.

As the practice of recent decades shows, these approaches to the problems of national development do not take into account the specifics of modern social development, global informatization and the lack of ideologies that would be a unifying factor in the "melting pot". And while implementing in modern EU countries the program on accepting the Muslim population from countries experiencing military and climatic cataclysms, "melting pot" does not work. Against the background of the low manifestation level of the mental traditions of the
European population, the strong mental traditions of immigrants, strengthened by a religious basis, hardened by the constant problems of survival in an unfavorable situation, proved to be much stronger. That is why the Muslim diasporas in France, Germany and other European countries are closed in the spheres of national and cultural identity. With the increase in the number of immigrants, they are increasingly trying to influence the social life of the host countries according to their ideas about the social order. Nowadays more and more often indigenous Europeans can hear from radical Muslims: "Your grandchildren will be Muslims!"

The growing importance of modern information processes in transformational activities, in cultural process and the development of self-awareness of society members, as well as the possibility of expanded ties of emigration with ethnically related cultural and religious centers, makes the policy of "melting pot" and multiculturalism in Western society ineffective. The attitude to immigration problems in modern conditions requires new approaches, new solutions with profound ideas about the functioning of mental mechanisms.

The studies of mental immunity, sources of mental resilience of society are essential in this process. In the context of modern immigration processes to Europe, understanding this concept is important both in terms of preserving the mentality of indigenous peoples and in terms of forming a tolerant, mutually acceptable policy on the mental immunity of Asian immigrants.

The emergence of mental immunity and its development occurs in the process of confronting the mental values of the individual and the social structure, to which he or she belongs, with the values of other social groups. In modern conditions, such confrontation occurs both at the interpersonal, verbal level and at the level of various information exchanges, including the influence of different arts, festive and ceremonial sphere. To a greater or lesser extent, religious beliefs have a mental component. To some extent, it is felt in the organization of labor, subject exchanges, especially in household items.

The multifaceted structure of mental immunity throughout the historical period, and especially at the informational stage of human development, receives an impetus for development both at the national level, at the level of ethnicity importance, and while shifting the emphasis of international issues development to certain areas, with the strengthening of relevant processes in some areas - political, cultural, etc.

In modern conditions, it should be taken into account that the strengthening of the immune system of mentality is influenced by the development of the humanities, the information foundation of the cultural process. Researchers mention two main factors in the selfidentification crisis of the citizens of the former Soviet 
republics: the collapse of this state and the rupture of the system of social ties established at that time. These factors are manifested in both positive and negative senses for generations that for decades have been accustomed to the system that existed, in which new generations of people developed.

During this period, "a heightened sense of existential inconsistency of one's existence and the world around forces a human to find spiritual support in the reproduction and comprehension of one's national history, those structures and events of joint character, which - with all the disorder of the modern historical situation - would allow a person to find certain points of "crystallization". And if until recently the axiological consciousness was focused mainly on the universality of the concept of culture and historical progress, then with the appeal to the problem of mentality (vital need for the development of personal qualities, personal significance in the social process (Authors' note)), the interest in national manifestations of human spirituality awakens, a number of ideas concerning, in particular, the national image of the world, the national type of life, the specifics of national character, etc., acquires appropriate substantiation" $[4$, p. 71].

At the forefront is the need to improve the organization of social order. "Mentality is legalized by identity in the process of self-awareness, selfdetermination of individuals, nations, societies... The difference between the democratization of states' public life, the uniqueness of their development process, i.e. the diversity of historical democracy progress, is common to the historical course of mankind, the assertion of pluralism in its compliance with the objective law of world development" [5, p. 230].

Earlier the works concerning the prospects of national development in the conditions of informatization have already emphasized the importance of this development as a civilizational mechanism of multivariate production in solving the growing number of global modern problems [6]. If to talk about the mental level of solving these problems, it is characterized by greater sophistication of responding to problems, a wider range of reactions and greater speed of the reactions to the situation. Obviously, there is a need for joint mobilization of the internal resource of mentally close people, their common mental qualities in the process of these responses.

Nowadays, the growing importance of the use of the mental resource of a modern human in the interests of social development raises two important problems:

- preserving the richness of the mentality of nations and ethnic groups, as well as the world present in the cultural traditions of the nations, strengthening mental immunity in the whole spectrum of its diversity and state lobbying the process of strengthening cultural traditions in all areas of possible influence on this process up to the formation and implementation of the relevant legal framework;

- ensuring the development of mental traditions as a process of conscious contribution to the potential for future development. After all, "the future is, in fact, not something ahead; it is what we actually create ourselves. The nature of this creation is influenced by the awareness of the national mentality structures. Therefore, philosophical reflection on mentality, the interaction of philosophers, sociologists, ethnopsychologists and political scientists in this regard is a necessary component of intellectualization and humanization of society..." [7, p. 4].

At the same time, each person with a different level of political literacy, national consciousness, with different educational baggage and ideas about the impact of information technology on consciousness is faced with all the powerful influences of the global information space. Taking into account the low level of information activity of the state and society, to which the user of information belongs, he or she may be (and often is) disoriented in matters of one's national development. At the individual level, it is mental immunity that can be a reliable mechanism for the formation of patriotically oriented, balanced landmarks of modern human life. Therefore, the work in this direction, in strengthening the stability of the immune system of the Ukrainian mentality is a very important task for Ukrainian science.

The solution to the problem of neutralizing the negative effects on mental immunity is consistent with the study of channels and sources of influence on the process of its development, functioning or neutralization. The most general approach to solving this problem is associated with the specifics of the manifestation of two main types of influence on the formation of mental characteristics of the individual and society: indirect influence of social information on the transformation of the individual's emotional sphere and direct influence on the emotional sphere, which is related to the mental motivations of genotypes derived from past generations.

The diversity of mental structure stereotypes determines the mental stability of the nation in a period of severe trials, the mental stability of the individual. And mental stability during a certain historical period is determined by the level of mental immunity development. This immunity is defined as a resource of resistance to external negative influences on the mentality and the process of its development in the conditions of the surrounding reality influence. Negative influences are manifested in the actions of uncontrolled information resources imported from outside the national information space [8], created in another cultural tradition and not adapted to the interests of the nation in the implementation of economic, political 
and other social goals in this or that country, the object of global influences.

At the same time, the foreign cultural tradition is reflected in all spheres of social activity of the leading globalization centers. In addition to information products, it is embedded in all the diversified goods and services that are the subject of exports in the context of globalization processes. In general, with the development of globalization, the effect of this mechanism on the objects of unequal globalization becomes total, multifaceted. It affects the whole mentality structure of the object of influence, gradually reduces the resistance of the immune system inherent in each nation to its deepest components - to mental immunity.

Mental immunity itself, according to the mental tradition, develops as a complex, multifaceted phenomenon, in the structure of which researchers distinguish the most actively manifested components:

“- political mentality;

- economic mentality;

- cultural mentality;

- labor mentality;

- religious mentality;

- social and domestic mentality;

- ecological mentality;

- ethnonational mentality

- youth mentality;

- nomenclature-bureaucratic mentality;

- totalitarian mentality, etc..." [9].

An important direction of scientific research in the field of mentality - and especially the formation of mental immunity - is the work associated with the support of the development process of the social structure of society. This process is associated with the formation of mental characteristics of new social structures that arise in the process of social evolution caused by the realities of the information society. In the conditions of the dynamics of social processes characteristic for today, the new social structures do not have the resources of time for the traditional formation of new mental guidelines and the corresponding immunity. Therefore, domestic science should equip the representatives of these structures with sound ideas about the national mentality in general, the traditions of its development, the relationship of mental features in the structure of the national environment, as well as generalize the course of these difficult processes in modern conditions.

As O. A. Bilous mentions, "the formation of a new socio-cultural environment is a prerequisite and at the same time the basis for the emergence of a qualitatively new mentality. This requires the solution of several important methodological problems, the main of which is the problem of ensuring continuity, preservation of traditions. There is another way - the way of rejecting ideas, on which a certain opposition to it invariably arises, the possibilities of its realization are inhibited. After all, the mentality of a nation may simply not be ready for certain changes if they go against the national tradition. This applies equally to the political, economic and cultural aspects of the problem..." [10, p. 140].

Important components of the modern mentality development are also the improvement of the expressive possibilities of revealing the content of spiritual wealth gained by all generations of the Ukrainian people. In this process, it is very important to reveal the richness of possibilities, smelted in the expressive reserves of the Ukrainian language, with the ancient roots of its evolution, with the socio-psychological factor, inseparable from the mental component of the Ukrainian genotype.

Thus, nowadays, the consideration of the problem of mentality and mental immunity is an important aspect of continuing research on the problems of national development in the context of increasing global influences. The development of these studies is associated with the growing demand for the results of humanities research in social practice, the need to significantly deepen these studies in the field of formation and development of mechanisms and patterns of social development based on historical practice, with the objective need to increase the conscious component in the growing complexity of modern society evolution.

Representatives of each ethnic group, including in the context of national minorities in the diaspora under favorable conditions for their activities, can make a significant contribution to national information creation. In the information stage of social development, based on a system of mental stereotypes, they can show mental, emotional and intellectual relations with other, united by common development trends in a single society, people who are guided by similar stereotypes of worldview and behavior, show identity in all areas of human activity, implement these guidelines in everyday life [11, p. 1112]. In the information and in all other spheres of activity, social structures based on mental unity and common development landmarks realize their development potential much more effectively than in a mentally diverse environment. This is evidenced by the examples of the post-socialist development period of mononational states from the former countries of the socialist camp in the process of implementing their European integration guidelines.

\section{CONCLUSIONS}

Thus, in modern conditions, under the influence of global informatization, the mental factors of national 
development, overshadowed by the rapid migration processes of the XIX-XX centuries, became more active. In our time, mentality restores the continuity of the historical memory of each nation in the public consciousness and introduces new information into the human consciousness, which contributes to the

\section{REFERENCES}

[1] Furman, A.V. (2002), Psykhokultura ukrainskoi mentalnosti: Naukove vydannia [Psychoculture of the Ukrainian mentality: Scientific publication], p. 12, Economic Thought, Ternopil, Ukraina.

[2] Bondarenko, O.V. (2005), Sutnist, istoriia ta suchasnist ukrainskoi ta zakhidnoievropeiskoi ekonomichnoi mentalnosti [The essence, history and modernity of the Ukrainian and Western European economic mentality], p. 111. Zaporizhzhia: ZNTU, Ukraina.

[3] Danylian, O.H. Dzoban, O.P. Kalinovsky, Yu.Yu. \& Moiseieva, N.I. (2004), Natsionalna bezpeka Ukrainy $v$ etno-mentalnomu ta mizhnarodnomu vymirakh: Monohrafiia [National Security of Ukraine in ethno-mental and international dimensions: Monograph], p. 124, Kharkiv, Ukraina.

[4] Bondarchuk, I.A. (1997), Sotsiokulturni formy vidobrazhennia mentalnosti $\mathrm{v}$ suchasnykh dukhovnykh i politychnykh protsesakh v Ukraini [Sociocultural forms of mentality reflection in modern spiritual and political processes in Ukraine]. Mentalnist $i$ dukhovno-politychni problemy formuvannia Zbroinykh Syl Ukrainy. Naukovyi zbirnyk [Mentality and spiritual and political problems of formation of the Armed Forces of Ukraine. Scientific collection], p. 71, Kyiv, Military Humanitarian Institute Kyiv, Ukraina.

[5] Lysenko, S.P. Chesnokov, V.O. Valihurskyi, Yu.O. and Fortova, O.I. (1997), Mentalitet Ukrainy yak osnova dukhovno-politychnykh peretvoren yii Zbroinykh Syl [Mentality of Ukraine as a basis of spiritual and political transformations of its Armed Forces]. Natsionalna mentalnist $i$ dukhovnopolitychni problemy formuvannia Zbroinykh Syl Ukrainy. Naukovyi zbirnyk [National mentality and spiritual and political problems of formation of the Armed Forces of Ukraine. Scientific collection], issue II, p. 230, Kyiv: KVGI, Ukraina. development of mental attitudes. In turn, the renewal of mental orientations in the worldview of modern people contributes to the evolution of nations in modern conditions, affects the activation of diaspora formations in the diverse palette of modern multinational states.

[6] Horovyi, V. M. (2015), Natsionalni informatsiini protsesy $\mathrm{V}$ umovakh hlobalizatsii [National information processes in the context of globalization], NAN Ukrainy, Nats. b-ka Ukrainy im. V.I. Vernadskoho [National Academy of Sciences of Ukraine, National Library of Ukraine named after V.I. Vernadskyi], Kyiv: NBUV, Ukraina.

[7] Kolisnyk, O.V.(2000), Osoblyvosti vtilennia ukrainskoi mentalnosti $v$ dukhovnomu prostori natsionalnoi kultury [Features of the Ukrainian mentality embodiment in the spiritual space of national culture], p. 4, Kyiv: Science world, Ukraina.

[8] Onishchenko, O.S. Horovyi, V.M. Popyk, V.I. and others (2014), Natsionalnyi informatsiinyi kompleks i yoho rol u hlobalnomu informatsiinomu prostori [National information complex and its role in the global information space], NAN Ukrainy, Nats. b-ka Ukrainy im. V.I. Vernadskoho [National Academy of Sciences of Ukraine, National Library of Ukraine named after V. I. Vernadskyi], Kyiv: NBUV, Ukraina.

[9] Bohynia D. P., Semykina M. V. (2003), Mentalnyi chynnyk u sferi pratsi: problemy teorii ta praktyky [Mental factor in the field of labor: problems of theory and practice], p. 350, Kyiv: "Storm", Ukraina.

[10] Bilous, A.O. (2003), Rozvytok ukrainskoi natsionalnoi mentalnosti $\mathrm{v}$ umovakh rozbudovy hromadianskoho suspilstva [Development of the Ukrainian national mentality in the conditions of civil society development], Derzhava $i$ pravo: Zbirnyk naukovykh prats. Yurydychni i politychni nauky [State and law: Collection of scientific works. Legal and political sciences], issue 19, p. 140. Kyiv: V. M. Koretsky Institute of State and Law of NAS of Ukraine, Ukraina.

[11] Onishchenko, O.S. Horovyi, V.M. Popyk, V.I. and others (2013), Informatsiia i modernizatsiia sotsiokulturnoi sfery suspilstva: vzaiemodiia ta rozvytok: monohrafiia [Information and modernization of the socio-cultural sphere of society: interaction and development: monograph], NAN Ukrainy, Nats. b-ka Ukrainy im. V.I. Vernadskoho [National Academy of Sciences of Ukraine, National Library of Ukraine named after V. I. Vernadskyi], Kyiv: NBUV, Ukraina. 